University of Nebraska - Lincoln

DigitalCommons@University of Nebraska - Lincoln

Faculty Publications: Department of

Entomology

Entomology, Department of

January 2008

\title{
Effects of the synergist S,S,S-tributyl phosphorotrithioate on indoxacarb toxicity and metabolism in the European corn borer, Ostrinia nubilalis (Hübner)
}

\author{
Analiza P. Alves \\ University of Nebraska-Lincoln, apiovesanalves2@unl.edu \\ William J. Allgeier \\ University of Nebraska-Lincoln \\ Blair D. Siegfried \\ University of Nebraska-Lincoln, bsiegfried1@ufl.edu
}

Follow this and additional works at: https://digitalcommons.unl.edu/entomologyfacpub

Part of the Entomology Commons

Alves, Analiza P.; Allgeier, William J.; and Siegfried, Blair D., "Effects of the synergist S,S,S-tributyl phosphorotrithioate on indoxacarb toxicity and metabolism in the European corn borer, Ostrinia nubilalis (Hübner)" (2008). Faculty Publications: Department of Entomology. 75.

https://digitalcommons.unl.edu/entomologyfacpub/75

This Article is brought to you for free and open access by the Entomology, Department of at DigitalCommons@University of Nebraska - Lincoln. It has been accepted for inclusion in Faculty Publications: Department of Entomology by an authorized administrator of DigitalCommons@University of Nebraska - Lincoln. 
Published in Pesticide Biochemistry and Physiology 90:1 (January 2008), pp. 26-30; doi:10.1016/j.pestbp.2007.07.005

Copyright (C) 2007 Elsevier Inc. Used by permission. http://www.sciencedirect.com/science/journal/00483575

Submitted March 8, 2007; accepted July 10, 2007; published online July 31, 2007.

\title{
Effects of the synergist $S, S, S$-tributyl phosphorotrithioate on indoxacarb toxicity and metabolism in the European corn borer, Ostrinia nubilalis (Hübner)
}

\author{
Analiza P. Alves, William J. Allgeier, and Blair D. Siegfried* \\ Department of Entomology, 202 Plant Industry Building, University of Nebraska-Lincoln, \\ Lincoln, NE 68583-0816, USA \\ * Corresponding author: B. D. Siegfried; fax 402 472-4687; email: bsiegfried1@unl.edu
}

\begin{abstract}
The toxicity of the oxadiazine insecticide indoxacarb to the European corn borer, Ostrinia nubilalis (Hübner) (Lepidoptera: Crambidae), was evaluated in the presence and absence of $S, S, S$-tributyl phosphorotrithioate (DEF), an inhibitor of hydrolytic metabolism. Bioassays involving topical application of different concentrations of indoxacarb to third instars of a susceptible $O$. nubilalis laboratory strain were performed, and in vitro metabolism experiments involving $\left[{ }^{14} \mathrm{C}\right]$ indoxacarb were examined to determine the role of hydrolytic metabolism in indoxacarb activation. Indoxacarb toxicity decreased in the presence of DEF indicating antagonism of toxicity. Results of in vivo and in vitro inhibition experiments indicated a reduction of indoxacarb activation and formation of the hydrolytic metabolite. These results are consistent with the proposed mechanism of hydrolytic activation for this compound.
\end{abstract}

Keywords: Ostrinia nubilalis, indoxacarb, oxadiazine, DEF, synergist, insecticide metabolism

\section{Introduction}

Indoxacarb is the first member of the oxadiazine insecticides and exhibits strong activity against lepidopteran pests of vegetables, tree fruits, cotton, corn, peanut, soybean, alfalfa and other crops [1]. Activity of this compound has also been shown against some homopteran and coleopteran species [2]. Indoxacarb is a highly active insecticide when ingested [2], although contact by direct spray or exposure to dried residue [3] has been shown to have activity in certain situations. Upon ingestion, larvae stop feeding after a short period of time and exhibit mild convulsions or a passive paralysis, which is an irreversible condition [4].

Indoxacarb is a pro-insecticide, and must undergo metabolic activation of the parent compound. This process involves hydrolysis to the $\mathrm{N}$-decarbomethoxyllated metabolite [4], which is much more toxic than the parent compound. The activated metabolite of indoxacarb has a unique mode of ac- tion involving the blocking of sodium channels of nerve cells, resulting in paralysis and death of the target pest species [5]. Neurotoxic symptoms lead to a rapid and irreversible cessation of feeding [2]. Symptoms of exposure to indoxacarb as a contact insecticide are similar but slower to develop [2]. Experiments involving indoxacarb metabolism in lepidopteran larvae indicate that at least $90 \%$ of the parent compound is converted to the activated metabolite $4 \mathrm{~h}$ after ingestion [2]. Tissue localization studies with fifth instar Manduca sexta larvae have shown that the fat body and midgut are the most active tissues catalyzing the activation of indoxacarb [4].

$S, S, S$-Tributyl phosphorotrithioate (DEF) is a widely recognized insecticide synergist that functions by inhibiting hydrolytic metabolism, and is commonly used in experiments involving metabolism of insecticides with ester linkages [6], [7] and [8]. Synergists are often used to inhibit detoxification in cases where resistance has evolved. However, as hydrolysis is a fundamental step in the activation of indoxacarb, it 
is anticipated that the use of DEF should antagonize toxicity by inhibiting activation of the parent compound. Metabolism studies in several lepidopteran larvae show that orally administered $\left[{ }^{14} \mathrm{C}\right]$ indoxacarb is rapidly converted to the decarbomethoxyllated metabolite [4], and the metabolic conversion is correlated with appearance of neurotoxic symptoms. However, there is little information regarding metabolism of topically applied indoxacarb.

The objectives of this study were to test the effects of the synergist DEF on indoxacarb toxicity and metabolism in $O s-$ trinia nubilalis (Hübner) when topically applied. Bioassays involving topical application of indoxacarb in the presence and absence of DEF and in vivo and in vitro inhibition by $\mathrm{DEF}$ of $\left[{ }^{14} \mathrm{C}\right]$ indoxacarb metabolism were compared. Results of these experiments provide insight into the role of hydrolytic metabolism in the activation of indoxacarb in a representative lepidopteran.

\section{Methods and materials}

\subsection{Insects and rearing}

Fourth instars were randomly selected from a susceptible $O$. nubilalis laboratory colony maintained at the University of Nebraska and used in all experiments. The laboratory colony was initially derived from field collections in 1995 [9] and reared for 90 generations without exposure to insecticides. Rearing methods were based on those developed at the USDA-ARS Corn Insect Research Unit, Ames, IA [10] and [11].

\subsection{Chemicals}

$\left[{ }^{14} \mathrm{C}\right]$ Indoxacarb $\left(27.3 \mathrm{mCi} \mathrm{mmol}^{-1}\right)$ and non-radiolabeled indoxacarb (95\% purity) were supplied by DuPont Agricultural Chemical (Newark, DE). $\left[{ }^{14} \mathrm{C}\right]$ Indoxacarb was purified by thin layer chromatography (TLC) using a $250 \mu \mathrm{m}$ thick silica plate (Sigma Chemical Company, St. Louis, MO). The plate was developed in toluene:acetone (70:30), and the labeled compound was identified by co-chromatography with a cold indoxacarb standard visualized under UV light. The radioactive band was scraped from the plate and eluted from the silica with repeated rinses in acetone. S,S,S-Tributyl phosphorotrithioate (DEF) was obtained from Chem Services (West Chester, PA).

\subsection{Bioassays}

Susceptibility of $O$. nubilalis to indoxacarb was determined by exposure of fourth instars to varying concentrations of indoxacarb prepared in acetone. Insecticide dilutions were topically applied to the dorsal abdomen in $1 \mu \mathrm{l}$ acetone using a Hamilton syringe (Reno, NV) with a repeating dispenser. Control larvae were treated with acetone only. To evaluate the effect of DEF on indoxacarb toxicity, both control and indox- acarb treated fourth instar $O$. nubilalis were treated with $1 \mu \mathrm{l}$ of $5 \mu \mathrm{g} / \mu \mathrm{l}$ DEF $4 \mathrm{~h}$ before treatment with indoxacarb. Larvae were placed in plastic Petri dishes after treatment and maintained at $27{ }^{\circ} \mathrm{C}, 24 \mathrm{~h}$ scotophase, and $80 \% \mathrm{RH}$. Treated larvae were provided with a wheat germ-based diet [10] throughout exposure. Mortality was evaluated at 24 and $48 \mathrm{~h}$ after treatment. Larvae that did not respond to probing were considered dead. A single bioassay consisted of seven doses of indoxacarb plus a control, with 16 larvae exposed at each concentration. Each bioassay was repeated three times. Dose-mortality data were analyzed by probit regression using POLO-PC [12] to calculate lethal doses and their $95 \%$ confidence intervals, slopes and their standard errors. Mortality was corrected for control mortality using the method of Abbott [13].

\subsection{In vivo inhibition experiments}

Fourth instars were topically treated with $0.5 \mu \mathrm{LEF}(5 \mu \mathrm{g} /$ $\mu \mathrm{l})$ or $0.5 \mu \mathrm{l}$ acetone (control) using a Hamilton syringe. Midguts of 40-60 treated larvae were dissected $4 \mathrm{~h}$ after treatment as described by Siqueira et al. [9] with slight modifications. Dissected midguts were vortexed briefly in ice-cold $0.2 \mathrm{M}$ sodium phosphate, $\mathrm{pH} 7.0$ (buffer A), and centrifuged for $5 \mathrm{~min}$ at $5000 \mathrm{~g}$ at $4{ }^{\circ} \mathrm{C}$ to remove gut contents. After centrifugation, the pelleted midgut tissue was weighed and homogenized in $1 \mathrm{ml}$ buffer A using a Potter-Elvehjem homogenizer. Midgut homogenates were centrifuged for $10 \mathrm{~min}$ at $12,000 \mathrm{~g}$, and the supernatant collected and filtered through glass wool. Protein concentration was determined using BCA protein assay (Pierce, Rockford, IL) [14], and esterase activity was quantified through assays with the model substrate $p$-nitrophenyl acetate (pNPA) as described by Zhou et al. [15].

To measure indoxacarb metabolism by midgut preparations, the $12,000 \mathrm{~g}$ supernatant from tissue homogenates was incubated with $\left[{ }^{14} \mathrm{C}\right]$ indoxacarb for $2 \mathrm{~h}$ at $30{ }^{\circ} \mathrm{C}$. The concentration of protein samples added to each reaction was approximately $0.7 \mathrm{mg} / \mathrm{ml}$ in a total volume of $500 \mu \mathrm{l}$. Reaction mixtures consisted of $50 \mu \mathrm{l}$ of the $12,000 \mathrm{~g}$ supernatant, $440 \mu \mathrm{l}$ buffer $\mathrm{A}$, and $4.4 \mu \mathrm{M}\left[{ }^{14} \mathrm{C}\right]$ indoxacarb (total volume of $500 \mu \mathrm{l})$. Each treatment was replicated three times and the entire experiment was repeated with two different preparations. To determine the rate of recovery and to measure nonenzymatic conversion of indoxacarb, control incubations consisting of $490 \mu \mathrm{l}$ buffer $\mathrm{A}$ and an equal concentration of $\left[{ }^{14} \mathrm{C}\right]$ indoxacarb were conducted. Reactions were stopped by vortexing with $500 \mu \mathrm{l}$ of ethyl acetate. A combined ethyl acetate extract $(2 \times 500 \mu l)$ of the incubation was evaporated to dryness under $\mathrm{N}_{2}$, dissolved in $30 \mu \mathrm{l}$ of acetone, and applied to a TLC plate which was developed in toluene:acetone (70:30) followed by dichloromethane:acetone:ethyl acetate (95:2:3). All samples, as well as the cold standards were applied to the TLC plate using disposable micropipettes. TLC plates were exposed to X-ray film (Kodak X-Omat AR) for 7 days at $-20{ }^{\circ} \mathrm{C}$. Radiolabeled indoxacarb and activated metabolite 
were identified by co-chromatography with cold standards, scraped from the plate, and eluted into scintillation cocktail $(10 \mathrm{ml})$ for radioactivity determination. Results were combined, transformed to percentage of total radioactivity for each radioactive band per lane, and analyzed using PROC MIXED [16]. Treatment means were separated by the least significant difference (LSMEANS) [16].

\subsection{In vitro inhibition experiments}

The $12,000 \mathrm{~g}$ supernatant from midgut homogenates obtained from untreated larvae were prepared as described previously. Protein concentration was determined using BCA protein assay. For activity assays, $2 \mu$ of acetone or DEF (3 or $0.3 \mathrm{mg} / \mathrm{ml}$ ) was added directly to $300 \mu \mathrm{l}$ of $12,000 \mathrm{~g}$ supernatant and incubated for $2 \mathrm{~min}$. Esterase activity in the presence and absence of DEF was quantified through assays with the model substrate $p$-nitrophenol acetate (pNPA). For in vitro inhibition of indoxacarb metabolism, the $12,000 \mathrm{~g}$ supernatant was incubated with radioactive indoxacarb as described previously. Incubation reactions contained $50 \mu \mathrm{l}$ of the $12,000 \mathrm{~g}$ supernatant, $430 \mu \mathrm{l}$ buffer $\mathrm{A}, 4.4 \mu \mathrm{M}\left[{ }^{14} \mathrm{C}\right]$ indoxacarb, and $10 \mu \mathrm{l}$ DEF $(10 \mathrm{mg} / \mathrm{ml})$ or $10 \mu \mathrm{l}$ acetone (total volume of $500 \mu \mathrm{l}$ ). The controls consisted of $480 \mu \mathrm{l}$ buffer $\mathrm{A}$, an equal concentration of $\left[{ }^{14} \mathrm{C}\right]$ indoxacarb and $10 \mu \mathrm{l} \mathrm{DEF}(10 \mu \mathrm{g} / \mu \mathrm{l})$ or $10 \mu \mathrm{lac}-$ etone. A combined ethyl acetate extract $(2 \times 500 \mu \mathrm{l})$ of the incubation was concentrated under $\mathrm{N}_{2}$ and analyzed by TLC as described for the in vivo experiments. Results were combined, transformed to percentage of total radioactivity and analyzed as described for in vivo inhibition experiments.

\section{Results and discussion}

\subsection{Bioassays}

Results from probit analysis of mortality data from the susceptible $O$. nubilalis laboratory population exposed to indoxacarb are presented in Table 1 . The $24 \mathrm{~h} \mathrm{LD}_{50}$ increased from 6.36 to $21.68 \mu \mathrm{g} / \mathrm{mg}$ in larvae pretreated with DEF. Mortality was consistently lower in larvae pretreated with DEF at all doses tested (Figure 1). A similar trend was observed at $48 \mathrm{~h}$, although the LD values generally decreased, which is consistent with the generally slower development of neurotoxic symptoms associated with indoxacarb toxicity. These results suggest that indoxacarb toxicity is antagonized by DEF.

\subsection{Inhibition experiments}

Fourth instars treated topically with DEF exhibited a 99.2\% reduction in hydrolytic enzyme activity from midgut preparations relative to untreated larvae (data not shown). DEF also caused significant in vitro inhibition of hydrolytic enzyme activity from midgut preparations resulting in $63.7 \%$ and $14.8 \%$ reductions at 33 and $3.3 \mu \mathrm{M} \mathrm{DEF}$, respectively (data not shown).

In metabolism experiments with $\left[{ }^{14} \mathrm{C}\right]$ indoxacarb, only two regions of radioactivity were identified by autoradiography, which corresponded to the indoxacarb parent and its active metabolite (Figure 2) based on co-chromatography with cold standards. In vitro inhibition experiments indicated that DEF significantly reduced the rate of conversion of indoxacarb to the activated metabolite (Figure 2 and Figure 3), reducing metabolite formation from $23.8 \%$ to $4.3 \%$ of total radioactivity in the absence and presence of DEF, respectively. Pretreatment of larvae with DEF prior to midgut dissections (in vivo inhibition) also resulted in reduced rates of indoxacarb activation (Figure 3), which accounted for $28.9 \%$ and $13.1 \%$ of total radioactivity in the absence and presence of DEF, respectively.

The results of these studies strongly support the nature of indoxacarb as a pro-insecticide that requires hydrolytic activation. Topical bioassays of indoxacarb in the presence and absence of the hydrolytic enzyme inhibitor DEF indicated significant antagonism of indoxacarb toxicity when larvae were pretreated with DEF. Moreover, DEF inhibited hydrolytic enzyme activity and strongly inhibited the formation of the activated metabolite both in vivo and in vitro. Hydrolytic activation of indoxacarb is unique among chemical insecticides, and may be particularly important in management of insect pests that have evolved resistance as a consequence of enhanced hydrolytic metabolism. If the same hydrolytic enzymes responsible for resistance to insecticide classes such as pyrethroids,

Table 1. Susceptibility of $O$. nubilalis third instars to indoxacarb in the presence and absence of DEF, 24 and $48 \mathrm{~h}$ after treatment

\begin{tabular}{|c|c|c|c|c|c|c|}
\hline Treatment & $N$ & Slope \pm SE & $\mathrm{LD}_{50}(95 \% \mathrm{CI})^{\mathrm{a}}$ & $\mathrm{LD}_{90}(95 \% \mathrm{CI})^{\mathrm{a}}$ & df & $\chi^{2 \mathrm{~b}}$ \\
\hline \multicolumn{7}{|c|}{$24 \mathrm{~h}$ after treatment } \\
\hline$-\mathrm{DEF}$ & 384 & $2.98 \pm .41$ & $6.36(4.9-8.1)$ & $17.12(12.0-32.3)$ & 5 & 5.7821 \\
\hline$+\mathrm{DEF}$ & 365 & $2.84 \pm .55$ & $21.68(17.1-29.0)$ & $61.08(41.5-133.4)$ & 5 & 2.8708 \\
\hline \multicolumn{7}{|c|}{$48 \mathrm{~h}$ after treatment } \\
\hline$-\mathrm{DEF}$ & 384 & $3.32 \pm .43$ & $3.33(\mathrm{na})^{\mathrm{c}}$ & $8.08(\mathrm{na})^{\mathrm{c}}$ & 5 & 38.244 \\
\hline$+\mathrm{DEF}$ & 365 & $2.49 \pm .40$ & $12.72(9.9-6.4)$ & $41.61(29.3-76.5)$ & 5 & 4.7574 \\
\hline
\end{tabular}

${ }^{a}$ Lethal doses expressed as $\mu \mathrm{g}$ indoxacarb/mg body weight.

${ }^{\mathrm{b}} \chi^{2}$ values obtained from POLO-PC output, indicating goodness-of-fit to the probit model.

${ }^{\mathrm{c}}$ Confidence intervals not calculated because data does not fit probit model $(P<0.05)$. 


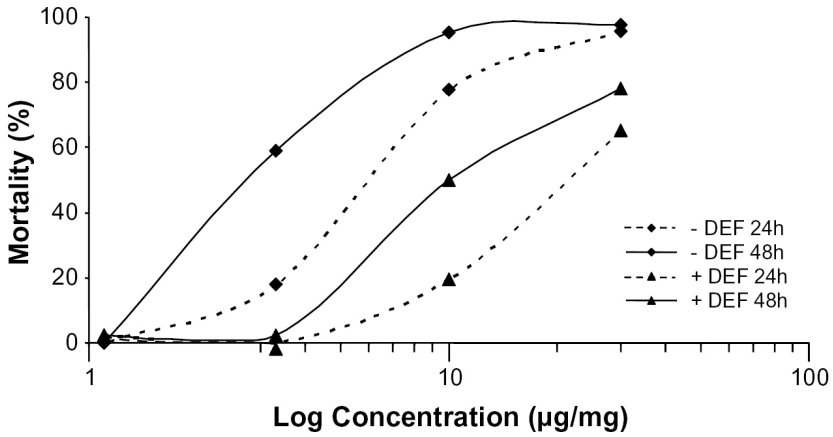

Figure 1. Response of $O$. nubilalis third instars to topically applied indoxacarb in the presence and absence of DEF at 24 and $48 \mathrm{~h}$.

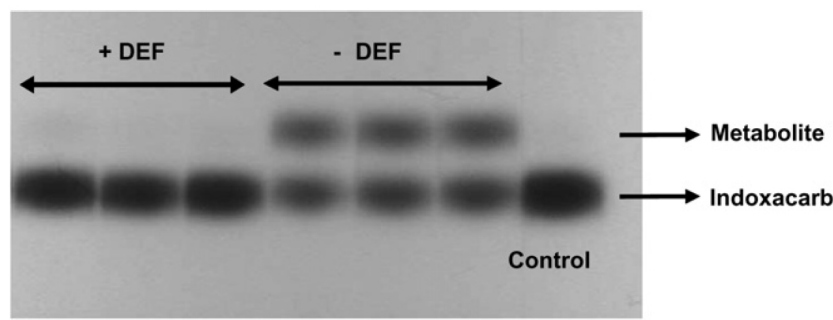

Figure 2. Autoradiogram from in vitro metabolism of $\left[{ }^{14} \mathrm{C}\right]$ indoxacarb by $12,000 \mathrm{~g}$ supernatant from $O$. nubilalis midgut homogenates in the presence and absence of DEF. The control lane represents incubation of $\left[{ }^{14} \mathrm{C}\right]$ indoxacarb in buffer only.

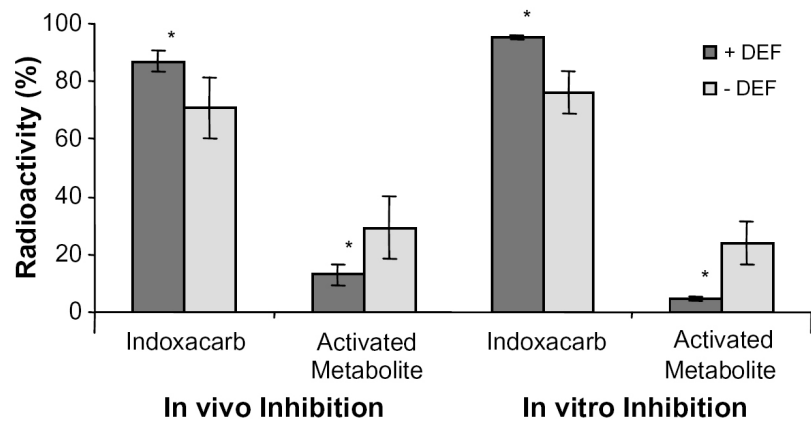

Figure 3. Percentage recovery of $\left[{ }^{14} \mathrm{C}\right]$ indoxacarb and its insecticidal metabolite formed during in vitro metabolism by $O$. nubilalis midgut preparations in the presence and absence of $\mathrm{DEF}$ (mean $\pm \mathrm{SE}$ ). In vivo inhibition refers to metabolism experiments conducted with $12,000 \mathrm{~g}$ supernatant from midgut homogenates prepared from larvae topically treated with DEF; in vitro inhibition refers to direct addition of DEF to reaction mixture. Significance of differences between treatments (presence of absence of DEF) indicated by * $(P<0.05$, PROC MIXED, LSMEANS $)$.

carbamates, and organophosphates are involved with activation of indoxacarb, the potential exists for negative cross-resistance to indoxacarb. A specific case of negative cross-resistance between pyrethroids and indoxacarb has been reported in Helicoverpa armigera in Australia based on bioassay data, suggesting that the same group of esterases are involved in both indoxacarb activation and pyrethroid resistance [17]. However, in the obliquebanded leafroller, Choristoneura ro- saceana (Lepidoptera: Tortricidae), DEF did not significantly affect indoxacarb susceptibility when exposed by ingestion and did not affect toxicity in strains shown to be resistant to other insecticide classes [17] and [18]. The potential for negative cross-resistance and antagonism of toxicity by DEF may be species specific or even population specific and broad generalizations should be avoided.

Importantly, results from this investigation suggest that integumental exposure to indoxacarb in the European corn borer involves similar mechanisms of activation to those associated with exposure by ingestion reported in other insects. Further clarification of the role of hydrolytic metabolism as well as tissue and species specific profiles of hydrolytic activation will further clarify the role of these processes in determining indoxacarb toxicity.

\section{Acknowledgments}

J. Smith contributed to initial bioassay experiments that were part of a laboratory exercise for the Insecticide Toxicology course at the University of Nebraska. Keith Wing from DuPont de Nemours and Company, Newark, Delaware, provided labeled insecticide and cold standards as well as input on experimental design. Dr. Erin Blankenship assisted with the statistical analyses.

\section{References}

[1] H.H. Harder, S.L. Riley, S.F. McCann and D.W. Sherrod, DPXMP062: a novel broad-spectrum, environmentally soft, insect control compound, Proceedings Beltwide Cotton Conferences vol. 1, New Orleans, LA (1997), pp. 48-50.

[2] K.D. Wing, M. Sacher, Y. Kagaya, Y. Tsurubuchi, L. Mulderig, M. Connair and M. Schnee, Bioactivation and mode of action of the oxadiazine indoxacarb in insects, Crop Prot. 19 (2000), pp. 537-545.

[3] N.J. Bostanian, C. Vincent, J.M. Hardman and N. Larocque, Toxic effects of indoxacarb to a predacious mirid and two species of predacious mites, Bull. OILB/SROP 27 (2004), pp. 31-35.

[4] K.D. Wing, M.E. Schnee, M. Sacher and M. Connair, A novel oxadiazine insecticide is bioactivated in lepidopteran larvae, Arch. Insect Biochem. Physiol. 37 (1998), pp. 91-103.

[5] A. Dinter and J.A. Wiles, Safety of the new DuPont insecticide "Indoxacarb" to beneficial arthropods: an overview, Bull. OILB/ SROP 23 (2000), pp. 149-156.

[6] L. Sun, X.G. Zhou, J. Zhang and X. Gao, Polymorphisms in a carboxylesterase gene between organophosphate-resistant and -susceptible Aphis gossypii (Homoptera: Aphididae), J. Econ. Entomol. 98 (2005), pp. 1325-1332.

[7] G.T. Payne and T.M. Brown, EPN and S,S,S-tributyl phosphorotrithioate as synergists of methyl parathion in resistant tobacco budworm larvae (Lepidoptera: Noctuidae), J. Econ. Entomol. 77 (1984), pp. 294-297.

[8] S. Kasai, I.S. Weerashinghe and T. Shono, P450 monooxygenases are an important mechanism of permethrin resistance in Culex quinquefasciatus Say larvae, Arch. Insect Biochem. Physiol. 37 (1998), pp. 47-56.

[9] H.A.A. Siqueira, K.W. Nickerson, D. Moellenbeck and B.D. Siegfried, Activity of gut proteinases from Cry1 Ab-selected col- 
onies of the European corn borer, Ostrinia nubilalis (Lepidoptera: Crambidae), Pest Manag. Sci. 60 (2004), pp. 1189-1196.

[10] L.C. Lewis and R.E. Lynch, Rearing the European corn borer, Ostrinia nubilalis (Hubner), on diets containing corn leaf and wheat germ, Iowa State J. Sci. 44 (1969), pp. 9-14.

[11] W.D. Guthrie, E.S. Raun, F.F. Dicke, G.R. Pesho and S.W. Carter, Laboratory production of European corn borer egg masses, Iowa State J. Sci. 40 (1965), pp. 665-683.

[12] LeOra in $P O L O-P C$, A user's guide to probit and logit analysis computer program, Berkeley, CA, 1987.

[13] W.S. Abbott, A method of computing the effectiveness of an insecticide, J. Econ. Entomol. 18 (1925), pp. 265-267.

[14] Protein assay technical handbook, Pierce Chemical Company, 2001, p. 38.
[15] X.G. Zhou, M.E. Scharf, L.J. Meinke, L.D. Chandler and B.D. Siegfried, Characterization of general esterases from methyl parathion-resistant and -susceptible populations of western corn rootworm (Coleoptera: Chrysomelidae), J. Econ. Entomol. 96 (2003), pp. 1855-1863.

[16] SAS Institute in SAS user's guide: statistics, vers. 8.2, SAS Institute Inc., Cary, NC, USA, 2001.

[17] R.V. Gunning and A.L. Devonshire, Negative cross-resistance between indoxacarb and pyrethroids in Australian Helicoverpa armigera: a tool for resistance management, Resistant Pest Manag. Newslett. 11 (2002), p. 52.

[18] M. Ahmad and R.M. Hollingworth, Synergism of insecticides provides evidence of metabolic mechanisms of resistance in the obliquebanded leafroller Choristoneura rosaceana (Lepidoptera: Tortricidae), Pest Manag. Sci. 60 (2004), pp. 465-473. 